\title{
OccurRence Of PATIENTS' agGressive behaVIOURS TOWARDS NURSES AND PARAMEDICS
}

\author{
Lucyna Płaszewska-Żywko1,A,C,D,E,F, Marcelina Podstawa ${ }^{1, B, C, D, E}$, Halina Milan²,A,B,C, Katarzyna Wojnar-Gruszka ${ }^{1, C, E}$, \\ Aurelia Sega ${ }^{1, C, E}$
}

'Department of Clinical Nursing, Institute of Nursing and Midwifery, Faculty of Health Sciences, Jagiellonian University Medical College, Krakow, Poland

${ }^{2}$ Emergency Department, Hospital of Dr Tytus Chałubiński in Zakopane, Poland

Authors' contribution:

A. Study design/planning • B. Data collection/entry $\bullet$ C. Data analysis/statistics $\bullet$ D. Data interpretation $\bullet$ E. Preparation of manuscript $\bullet$ F. Literature analysis/search $\bullet$ G. Funds collection

\author{
Address for correspondence: \\ Lucyna Płaszewska-Żywko \\ Department of Clinical Nursing \\ Institute of Nursing and Midwifery \\ Faculty of Health Sciences \\ Jagiellonian University Medical College \\ 25 Kopernika St. \\ 30-501 Krakow, Poland \\ e-mail: lucyna.plaszewska-zywko@uj.edu.pl \\ SUBMITTED: 17.10 .2019 \\ ACCEPTED: 15.11 .2019 \\ DOl: https://doi.org/10.5114/ppiel.2019.92535
}

\begin{abstract}
Introduction: Aggression is a complex phenomenon, which can take various forms. In recent years an intensification in patients' aggressive behaviours toward medical staff has been observed. It should be the reason for further research in this field.

Aim of the study: To estimate the prevalence of patients' aggressive behaviours towards nurses and paramedics. Material and methods: The study was conducted in two hospitals in the Małopolska region. The study group included 99 nurses working at the emergency department, surgical, internal, and orthopaedic wards and 13 paramedics from the emergency department. A diagnostic survey method was performed using a self-developed questionnaire. Statistical analysis was performed using $\chi^{2}$ test and Spearman test. The significance level was $p=0.05$

Results: The staff were quite often exposed to patients' aggressive behaviours in the workplace. The various types of physical violence were often experienced by $8.0 \%$ of respondents. More than $1 / 4$ of the group faced different forms of verbal aggression. Medical staff working at emergency department experienced verbal aggression much more frequently than the group from other wards $(p<0.05)$. Although some respondents declared their participation in communication courses, no significant result of such training in decreasing exposure to patients' aggression has been shown.

Conclusions: The occurrence of patient aggression towards nurses and medical rescuers, especially on emergency departments, was quite common and usually manifested in the form of verbal aggression. Preparation for dealing with aggressive patients was insufficient in the examined group.
\end{abstract}

Key words: patient, aggression, nurses, paramedics.

\section{INTRODUCTION}

Health professionals taking care of persons with physical and mental disturbances are often exposed to patients' aggression [1]. In 1996, the $49^{\text {th }}$ World Health Assembly declared violence a major and growing global public health problem [2]. The European Commission has defined workplace violence as: "Incidents where staff are abused, threatened, or assaulted in circumstances related to their work, including commuting to and from work, involving an explicit or implicit challenge to their safety, well-being, and health" [3]. Patient aggression towards health care professionals, especially nurses and paramedics has been documented in several studies [4-7]. There are some risk factors associated with violent behaviour such as: head injury, alcohol and drug abuse, hypoxia, psychiatric disease, metabolic disease, and side effects of medications [7]. Therefore, staff members working in mental health settings and in emergency departments are at higher risk of being assaulted by patients $[1,7,8]$. Occurrence of violence in the workplace has been found to be associated with anxiety, fear, guilt, sleep disturbances, dissatisfaction with work, burnout, and poor self-rated health in health care professionals [1]. Many reports of national organisations recommend employee training programs to quickly recognise the risk of violence occurrence and techniques that can prevent such a phenomenon $[1,6]$. 


\section{AIM OF THE STUDY}

The aim of the study was to estimate the prevalence of patients' aggressive behaviours toward nurses and paramedics.

\section{MATERIAL AND METHODS}

The study was conducted in two hospitals in the Małopolska region from December 2017 to March 2018, after obtaining the approval of the hospital directors. The study group consisted of 99 nurses working at emergency departments, surgical, internal, and orthopaedic wards and 13 paramedics from emergency departments. A self-developed questionnaire was used, including sociodemographic data, questions on education, professional experience, training courses, work-related violence exposure, and some elements of SOAS-R (the Staff Observation Aggression Scale). Questions quantifying the occurrence of patients' aggressive behaviours were scored on a five-point Likert scale, where: 1 - never, 2 - almost never (1-3 times every half a year), 3 - sometimes (1-3 times a month), 4 - often (every $3^{\text {rd }} 5^{\text {th }}$ shift), and 5 - very often (almost every shift). Statistical analysis was performed using Statistica v. 7.1 (StatSoft) and MS Excel (Microsoft). Normal distribution was verified using the Kolmogorov-Smirnov test, Lilliefors test, and Shapiro-Wilk $W$-test. Nominal data were examined with the $\chi^{2}$ test, and the significance level was $p<0.05$. The Spearman test was used to measure the relationship between the ordinal variables.

\section{RESULTS}

Most respondents were women ( $n=98,87.5 \%)$. The mean age of subjects was $40.8 \pm 10.3$ years. The majority of the group ( $n=45,40.2 \%)$ had a bachelor's degree in nursing and $13(11.6 \%)$ in paramedic science. There were 39 (34.8\%) subjects who completed post-secondary nursing school, and 15 (13.4\%) had a master's degree in nursing. The work experi- ence was between 4 months and 37 years (mean 18.5 years).

The group of $29.6 \%$ subjects had completed different forms of postgraduate courses, which included basics of therapeutic communication, but not specific courses on how to deal with aggressive patients.

The study showed that the staff were quite often exposed to various types of patient aggression in the workplace. The most common types of physical violence were pushing, scratching, and kicking. What is more, $12.5 \%$ of the subjects at least sometimes had had health problems related to patients' aggressive behaviour (Table 1).

More often respondents experienced passiveaggressive behaviours, e.g. hostility and resentment, which $32.1 \%$ of them report every $3^{\text {rd }}-5^{\text {th }}$ shift, and $18.8 \%$ on almost every shift. Twenty-one per cent of the subjects reported that they had dealt with patients who were unwilling to cooperate (almost every shift), and $32.0 \%$ of them experienced such a situation every $3^{\text {rd }}-5^{\text {th }}$ shift. Almost half of the group (41.1\%) were exposed 1-3 times a month to different forms of verbal aggression like vulgar vocabulary, swearing, and words that expressed contempt (Table 2).

The other types of aggression that were demonstrated by the patients were barging, self-aggression behaviours, destroying medical equipment, bullying, insulting, threatening, and blackmail (15.2\% of answers). Almost half of the study group (43.8\%) maintained that exposure to physical aggression from the patients was common, and $52.7 \%$ of the group claimed a very high risk of verbal aggression during their work.

Aggression from patients' relatives was also a significant problem. Seventy-nine per cent of respondents faced that kind of violence in their practice, and only $13.0 \%$ did not experience it. Staff working at emergency departments experienced vulgar vocabulary more often than the groups from other wards $(p=0.002)$. As many as $67.0 \%$ of the group experienced that phenomenon every $3^{\text {rd }}-5^{\text {th }}$ shift (Figure 1).

Table 1. Frequency of different types of physical aggression experienced by nurses and medical rescuers

\begin{tabular}{lccccc}
\hline Physical aggression forms & $\begin{array}{c}\text { Never } \\
n(\%)\end{array}$ & $\begin{array}{c}\text { Almost never } \\
n(\%)\end{array}$ & $\begin{array}{c}\text { Sometimes } \\
n(\%)\end{array}$ & $\begin{array}{c}\text { Often } \\
n(\%)\end{array}$ & $\begin{array}{c}\text { Very often } \\
n(\%)\end{array}$ \\
\hline Hitting & $50(44.6)$ & $44(39.3)$ & $16(14.3)$ & $0(0.0)$ & $2(1.8)$ \\
\hline Biting & $82(73.2)$ & $19(17.0)$ & $11(9.8)$ & $0(0.0)$ & $0(0.0)$ \\
\hline Kicking & $33(29.5)$ & $51(45.5)$ & $25(22.3)$ & $2(1.8)$ & $1(0.9)$ \\
\hline Pushing & $26(23.2)$ & $38(33.9)$ & $35(31.3)$ & $9(8.0)$ & $4(3.6)$ \\
\hline Scratching & $33(29.5)$ & $41(36.6)$ & $31(27.6)$ & $6(5.4)$ & $1(0.9)$ \\
\hline Pulling hair & $96(85.7)$ & $10(8.9)$ & $5(4.5)$ & $1(0.9)$ & $0(0.0)$ \\
\hline Other forms of physical assault & $63(56.3)$ & $32(28.5)$ & $13(11.6)$ & $1(0.9)$ & $3(2.7)$ \\
\hline Health damage experience & $73(65.2)$ & $25(22.3)$ & $10(8.9)$ & $2(1.8)$ & $2(1.8)$ \\
\hline
\end{tabular}

Almost never -1-3 times every half a year, sometimes - 1-3 times a month, often - every $3^{\text {rd }}-5^{\text {th }}$ shift, very often - almost every shift 
Table 2. Frequency of different types of verbal aggression experienced by nurses and medical rescuers

\begin{tabular}{|c|c|c|c|c|c|}
\hline Verbal aggression forms & $\begin{array}{l}\text { Never } \\
n(\%)\end{array}$ & $\begin{array}{c}\text { Almost never } \\
n(\%)\end{array}$ & $\begin{array}{c}\text { Sometimes } \\
n(\%)\end{array}$ & $\begin{array}{l}\text { Often } \\
n(\%)\end{array}$ & $\begin{array}{c}\text { Very often } \\
n(\%)\end{array}$ \\
\hline Vulgar vocabulary & $5(4.5)$ & $14(12.5)$ & $46(41.1)$ & $40(35.7)$ & $6(5.4)$ \\
\hline Swearwords & $4(3.6)$ & $15(13.4)$ & 47 (41.9) & $35(31.3)$ & $11(9.8)$ \\
\hline Using irony & $8(7.1)$ & 19 (17.0) & $42(37.5)$ & $29(25.9)$ & $14(12.5)$ \\
\hline Using contempt & $9(8.0)$ & $19(17.0)$ & $46(41.1)$ & $29(25.9)$ & $9(8.0)$ \\
\hline Verbal skirmish & $11(9.8)$ & $18(16.1)$ & $43(38.4)$ & $30(26.8)$ & $10(8.9)$ \\
\hline
\end{tabular}

A strong statistically significant difference was found between wards in signs of contempt in patients' statements towards medical staff $(p=0.003)$. Almost half of the professionals from emergency departments had to deal with this problem every $3^{\text {rd }}-5^{\text {th }}$ shift, and $13.0 \%$ of them experienced verbal aggression on almost every shift. By comparison, $34.0 \%$ of the internal ward nurses almost never and $16.0 \%$ nev-

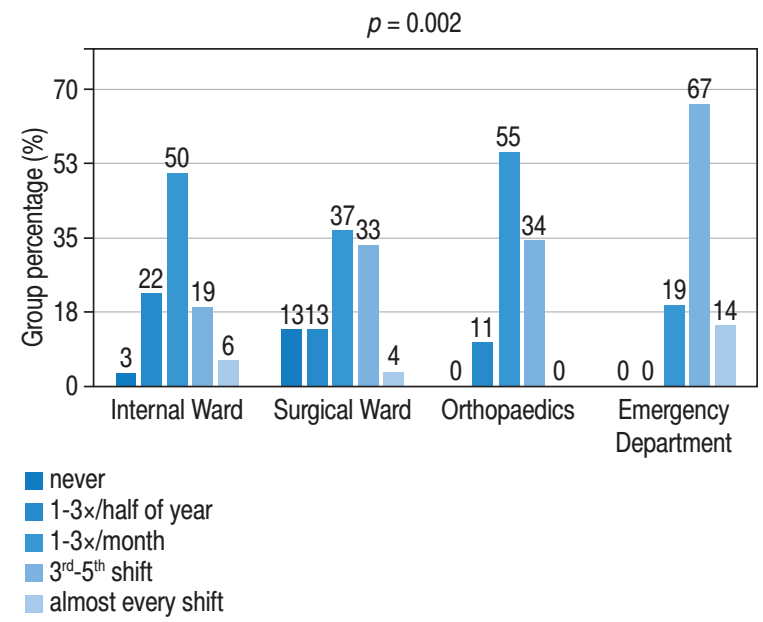

Figure 1. Frequency of patients' vulgar vocabulary occurrence in the workplace

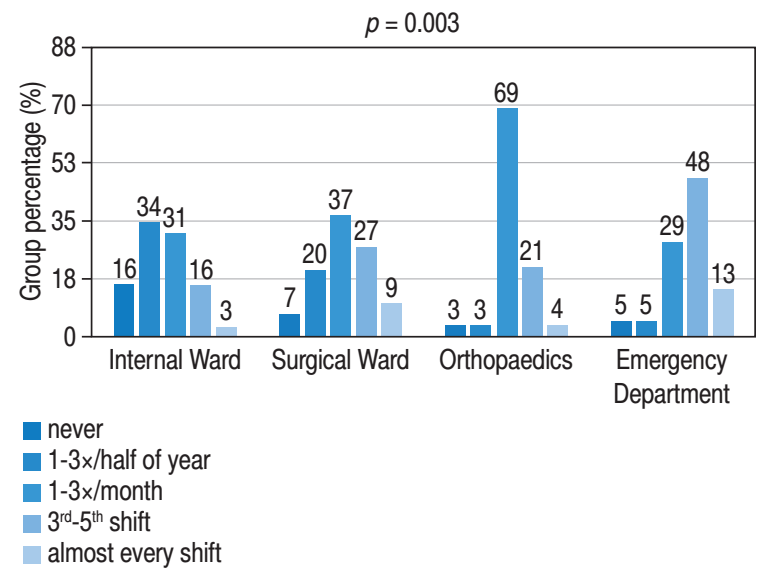

Figure 2. Frequency of signs of contempt occurrence in the workplace er had experienced signs of contempt in the patient's comments (Figure 2).

The emergency department group had been much more exposed to verbal aggression in the form of swearing $(p=0.01)$, verbal skirmishes $(p=0.049)$, and ironic comments $(p=0.032)$. Additionally, occurrence of verbal aggression in general, has been more frequent in the emergency department than in other departments, but it is also noticeable that the orthopaedic ward staff experienced that phenomenon quite often $(p=0.029)$. Fifty-seven per cent of emergency department staff had faced verbal abuse on almost every shift. This problem applied to $43.0 \%$ of the emergency department team as well as to $62.0 \%$ of the orthopaedics staff every $3^{\text {rd }}-5^{\text {th }}$ shift (Figure 3 ).

No strong relationship between the workplace and physical violence occurrence was shown. Generally, both nurses and paramedics were exposed to this type of aggression at a similar frequency. However, "kicking" was the most common type of aggression in the surgical ward, where $30.0 \%$ nurses experienced such a situation 1-3 times a month. The same applied to $28.1 \%$ of internal ward nurses ( $p=0.01$ ). The "hitting" episodes most frequently occurred in internal wards, where $25.0 \%$ of respondents had experienced that kind of physical aggression 1-3 times a month, and $46.9 \%$ of them $1-3$ times

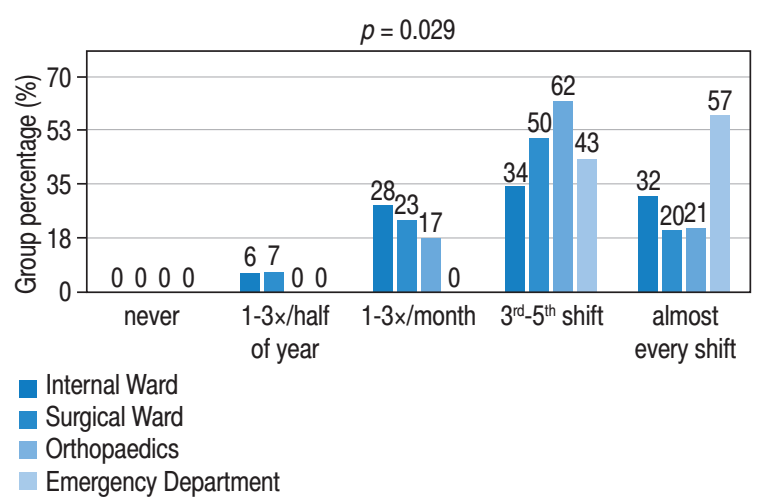

Figure 3. Verbal aggression occurrence in the workplace 
every six months $(p=0.055)$. There was no statistically significant relationship between the exposure to different types of patient aggression and the level of education or the age of respondents. Additionally, the analysis did not show any significant effect of completing communication training regarding exposure to patient aggression.

\section{DISCUSSION}

Patients' aggression towards health care professionals is a common phenomenon. This is confirmed by many studies and reports $[5,9,10]$. Every member of the medical team can meet aggression in the workplace. Mroczek et al. showed that $33.3 \%$ of medical staff feel victim to patient aggression every day [11]. However, nurses and paramedics are the groups that are most often exposed to patients' aggressive behaviours, as was shown in the study conducted by De La Fuente et al. and Ramacciati et al. [1, 7, 12, 13]. According to De La Fuente, 95.2\% of nurses working in different areas experienced or saw patients' or visitors' violence at least once in their career. A large group (57.1\%) experienced that 1-5 times in the past year and $42.9 \%$ more than 10 times [12]. This study corresponds with observations made by Speroni et al., in which $76.0 \%$ of nurses experienced violence by a patient or visitor in a one-year period [14]. This major problem was also shown in our research, in which $79.0 \%$ of respondents had been exposed to aggression from visitors during their practice.

Aggression can take different forms. Physical aggression is generally presented less often than verbal; nevertheless, in this study $43.8 \%$ of the respondents pointed out that exposure to physical aggression from patients such as pushing, scratching, and kicking is common. The study showed that $23.3 \%$ of the subjects had health problems related to patients' aggressive behaviour. Similar study results were obtained by Mroczek et al., where $41.3 \%$ of respondents experienced offensive harmful behaviour from patients, and $19.0 \%$ had been injured [11]. As suggested by the study by Płotka et al. $70.0 \%$ of nurses experienced a physical threat from patients [15]. A literature review conducted by Kowalenko et al. and a study by Kowalczuk et al. confirmed that emergency department nurses and paramedics report higher rates of physical aggression than other groups [16-18].

Verbal aggression is the most frequent type of aggression towards nurses and paramedics [4, 14, 19]. Merecz et al. presented that screaming is the most common behaviour, which is experienced by $89.6 \%$ of medical staff [20, 21]. These study results are similar to observations made by Kowalczuk and KrajewskaKułak, who noticed that the group of $36.7 \%$ nurses and $29.4 \%$ medical rescuers experienced patients' raised voice in their everyday practice [18]. In our study nurses and paramedics working in emergency departments were exposed to vulgar vocabulary more often than the group from other wards. They had to deal with this problem every $3^{\text {rd }}-5^{\text {th }}$ shift, while $14.0 \%$ of them experienced verbal aggression on almost every shift. This is also confirmed by respondents' claims that there is a very high risk of verbal aggression during their work (52.7\%). Significantly common were behaviours like swearing, verbal skirmishes, and ironic comments. Such results were also reported by other authors [11]. As suggested by other studies, threats and blackmail are becoming more common in emergency departments [11]. Calow et al. as well as Lenaghan et al. suggest that using aggression risk assessment tools and employee training programs is crucial for violence prevention [22, 23]. In our study only $29.6 \%$ of nurses and paramedics declared that they had completed training on basic therapeutic communication, but no significant result of such training in terms of reducing exposure to violence was shown. Therefore, there is a need for training in dealing with patient aggression [24].

\section{CONCLUSIONS}

The occurrence of patients' aggression towards nurses and medical rescuers was quite common and usually manifested in the form of verbal aggression.

The aggression from the patients and their families was most frequently experienced by the staff of hospital emergency departments.

Preparation for dealing with aggressive patients was insufficient in the examined group.

To sum up, nurses and paramedics, especially in emergency departments, are often exposed to patients' aggressive behaviours caused by many factors. Further research is needed to explore this problem and to implement reliable methods to reduce it.

\section{Disclosure}

The authors declare no conflict of interest.

\section{References}

1. Pekurinen V, Willman L, Virtanen M, et al. Patient aggression and the wellbeing of nurses: a cross-sectional survey study in psychiatric and non-psychiatric settings. Int J Environ Res Public Health 2017; 14: 1245.

2. Rutherford A, Zwi A, Grove N. Violence: a glossary. J Epidemiol Community Health 2007; 61: 676-680.

3. https://osha.europa.eu/en/publications/workplace-violence -and-harassment-european-picture (Accessed: 8 November 2019).

4. Kowalczuk K, Jankowiak B, Krajewska-Kułak E, et al. Ocena stopnia narażenia ratowników medycznych na agresję w miejscu pracy. Roczniki Polskiej Akademii Medycznej w Szczecinie 2009; 55: 76-80.

5. Lickiewicz J, Piątek J. Doświadczanie agresji w pracy pielęgniarskiej. Sztuka Leczenia 2014; 3-4: 11-22. 
6. Merecz D, Mościcka A. Przemoc w placówkach służby zdrowia i sposoby jej przeciwdziałania. Instytut Medycyny Pracy im. J. Nofera, Łódź 2003; 59-76.

7. Bowers L, Douzenis A, Galeazzi GM, et al. Disruptive and dangerous behaviour by patients on acute psychiatric wards in three European centres. Soc Psychiatry Epidemiol 2005; 40: 822-828.

8. Frydrysiak K, Ejdukiewicz J, Grześkowiak M. Agresja pacjentów $\mathrm{i}$ ich rodzin wobec personelu Szpitalnego Oddziału Ratunkowego. Anest Ratow 2016; 10: 46-52.

9. Szwamel K, Sochocka L. Opinia średniego personelu medycznego szpitalnego oddziału ratunkowego na temat agresywnych zachowań pacjentów. Pielęgniarstwo i Zdrowie Publiczne 2014; 4: 149-154.

10. Skirzyńska-Podgórska M, Bulsa M. The analysis of patient aggression forms towards medical personnel. E-Dentico 2010; 3: 20-31.

11. Mroczek B, Mormul J, Kotwas A, et al. Patient aggression towards health care professionals. Prog Health Sci 2014; 4: 67-74.

12. De La Fuente M, Schoenfisch A, Wadsworth B, et al. Impact of behaviour management training on nurses' confidence in managing patient aggression. J Nurs Adm 2019; 49: 73-78.

13. Ramacciati N, Ceccagnoli A, Addey B, et al. Violence towards emergency nurses: A narrative review of theories and frameworks. Int Emerg Nurs 2018; 39: 2-12.

14. Speroni KG, Fitch T, Dawson E, et al. Incidence and cost of nurse workplace violence perpetrated by hospital patients or patient visitors. J Emerg Nurs 2014; 40: 218-228.

15. Płotka A, Pitek A, Makara-Studzińska M. Stres a zespół wypalenia zawodowego. Pielęg 2000 1998; 5: 26-30.

16. Kowalenko T, Cunningham R, Sachs CJ, et al. Workplace violence in emergency medicine: current knowledge and future directions. J Emerg Med 2012; 43: 523-531.

17. Kowalczuk K, Jankowiak B, Krajewska-Kułak E, et al. Comparison of the level of aggression towards healthcare workers within Podlaskie Voivodeship. Int J Occup Med Environ Health 2011; 24: 267-274.

18. Kowalczuk K, Krajewska-Kułak E. Patient aggression towards different professional groups of healthcare workers. Ann Agricult Environ 2017; 24: 113-116.

19. Lickiewicz J, Marzęcka A, Makara-Studzińska M. Analiza porównawcza zachowań agresywnych na SOR i oddziale chirurgii - doniesienie wstępne. Anestezjologia i Ratownictwo 2018; 12: 266-273.

20. Merecz D, Rymaszewska J, Mościcka A, et al. Violence at the workplace - a questionnaire survey of nurses. Eur Psychiatry 2006; 21: 442-450.

21. Merecz D, Waszkowska M. Informacje na temat zachowań psychospołecznych w środowisku społecznym w miejscu pracy. Instytut Medycyny Pracy im. J. Nofera, Łódź 2007; 5-37.

22. Callow N, Lewis A, Showen S, et al. Literature synthesis: patient aggression risk assessment tools in the emergency department. J Emerg Nurs 2016; 42: 19-24.

23. Lenaghan PA, Cirrincione N, Henrich S. Preventing emergency department violence trough design. J Emerg Nurs 2018; 44: 7-12.

24. Wojnicka D, Włoszczak-Szubzda A. Wiedza i umiejętności personelu medycznego $\mathrm{w}$ odniesieniu do przejawów agresji ze strony pacjenta. Aspekty Zdrowia i Choroby 2017; 2: 51-63. 